\title{
ANALISIS PRODUKTIVITAS PROSES PAINTING DENGAN PENDEKATAN METODE OVERALL EQUIPMENT EFFECTIVENESS (STUDI KASUS PT. SAKAE RIKEN INDONESIA)
}

\author{
${ }^{1}$ Afif Hakim \\ ${ }^{2}$ Sri Pramono \\ Teknik Industri, Fakultas dan Ilmu Komputer \\ Universitas Buana Perjuangan Karawang \\ Email:afif.hakim@ubpkarawang.ac.id,sripramono887@gmail.com
}

\begin{abstract}
ABSTRAK
Pengukuran produktivitas penting dilakukan agar perusahaan dapat mengevaluasi kinerjanya. Salah satu metode pengukuran produktivitas adalah Overall Equipment Effectiveness (OEE). Pengukuran OEE menggunakan 3 rasio yaitu avaibility, performance, quality. Hasil dari perhitungan OEE tahun produksi 2018 sebesar 42,56 \%, dilihat dari besarnya OEE tersebut dikategorikan ke dalam kategori 2 (40\% - 59\%) atau kategori rendah sehingga perlu dilakukan perbaikan sistem karena berpeluang akan menimbulkan kerugian dan daya saing rendah. Penyumbang terbesar rendahnya nilai OEE adalah pada aspek quality, dengan jenis losses yaitu defect losses dengan rasio $44,60 \%$. Usulan perbaikan yang dilakukan adalah dengan menerapkan pendekatan kaizen 5S. Setelah dilakukan perbaikan selama 5 bulan didapatkan hasil perhitungan OEE sebesar 44,10 \%. Jika dibandingkan dengan data tahun 2018 dengan nilai OEE 42,56\%, maka mengalami kenaikan sebesar 1,54\%. Dengan demikian, diharapkan perusahaan dapat terus meningkatkan performa produktivitasnya di masa-masa mendatang.
\end{abstract}

Productivity measurement is important so that companies can calculate their performance. One method of measuring productivity is the Overall Effectiveness of Equipment (OEE). The measurement of OEE uses 3 ratios, namely availability, performance, quality. The results of the OEE calculation for the 2018 production year were $42.56 \%$, the contribution of OEE was categorized into category $2(40 \%-59 \%))$ or low category so it is necessary to improve the system because it is likely to cause losses and low competitiveness. The biggest contributor to the value of OEE is in the quality aspect, with the type of loss, namely defect losses with a ratio of $44.60 \%$. After 5 months of improvement, the OEE calculation result was $44.10 \%$, compared to the 2018 data with an OEE value of $42.56 \%$, an increase of $1.54 \%$, so the company is expected to continue to improve its productivity performance. in the future.

\section{PENDAHULUAN}

Sektor industri adalah salah satu sektor yang mempunyai peranan sangat berpengaruh dalam pertumbuhan pembangunan nasional. Hal ini mendorong setiap perusahaan untuk dapat memproduksi produk yang berkualitas dan memiliki nilai lebih, sehingga mendapat 
kepercayaan dari konsumen. Persepsi konsumen akan berdampak pada peningkatan permintaan terhadap produk yang dihasilkan oleh suatu industri, dengan kata lain perusahaan mempunyai kemampuan untuk bersaing di pasaran. Suatu produk memiliki nilai tambah apabila kualitas bagus, harga terjangkau, dan produk tersedia pada saat konsumen membutuhkan. Perusahaan dikatakan mampu dalam melakukan efisiensi pada proses produksi apabila tiga kriteria tersebut dapat dicapai. Sedangkan untuk mencapai efisiensi produksi ada 3 hal yang perlu dicapai yaitu kesiapan, keandalan perusahaan, dan termasuk kontinuitas proses produksi. Maka perawatan fasilitas produksilah upaya yang dapat dilakukan untuk mencapai kesiapan, dan keandalan tersebut.

Persaingan perusahaan dalam memuaskan kebutuhan pelanggan dan meningkatkan laba perusahaan sesuai dengan target yang ingin dicapai. Segala cara dipergunakan perusahaan guna mencukupi kebutuhan-kebutuhan dari konsumenimereka. Kebutuhan konsumen yang bermacam-macam memaksa perusahaan untuk pintaridalam menentukan keputusan. supaya perusahaan terus menerus produktif, ketersediaannya fasilitas industri sangat diperlukan.

Perawatan adalah bagian dari kegiatan bisnis perusahaan dan mengambil peran utama dalam keberhasilan suatu organisasi. Untuk menjaga kualitas dan meningkatkan produktivitas, salah satu penyebab penting yang perlu difokuskan adalah problem pemeliharaan mesin (maintenance) dan peralatan produksi. Menurut Kurniawan (2013), manajemen pemeliharaan industri adalah cara pengaturan aktivitasi untuk menjaga kelangsungan produksi, sehingga dapat menghasilkan produk yang berkualitas dan berdaya saing, melalui pemeliharaan fasilitas perusahaan. Manajemen perawatan industri sendiri diperlukan guna meminimasi downtime. Sehingga proses produksi bahan baku menjadi produk jadi dapat berjalan dengan baik. Selain itu berawal dari keinginan manusiaiuntuk mendapatkan kenyamanan dan keamanan terhadap obyek yang dipunyai, dan untuk mempunyai sistem yang lebih teratur, rapih, bersih dani fungsional. Oleh sebab itu, peranan perawatan fasilitas tersebut sangat diperlukan dalam mendukung performansi pekerjaan serta kontinuitas produksi.

Overall Equipment Effectiveness (OEE) diartikan sebagai "metric atau ukuran guna menilai efektivitas fasilitas yang berupaya untuk mengetahui kehilangan produksi dan anggaran lain yang tak langsung, tersembunyi yang mempunyai andil besar terhadap anggaran total produksi”. Defisit tersebut "dirumuskan sebagai fungsi dari sejumlah komponen eksklusif yang berkaitan", yaitu : Avaibility, Performance dan Quality. Secara keseluruhan nilai efektivitas mesin/produksi dijelaskan dengan indeks Overall Equipment Effectiveness 
$(O E E)$. OEE mendeskripsikan pengguanaan mesin secara nyata terhadap ketersediaan dan telah memperhatikan jumlah produk yang telah dihasilkan, serta cacat produk yang terjadi.

PT. Sakae Riken Indonesia adalah salah satu cabang perusahaan Sakae Riken Corporation yang bertempat di Jepang. Sakae Riken Corporation kini berkembang semakin luas dengan berbagai cabang di dunia seperti Jepang sebagai kantor pusat, Tiongkok, Indonesia, dan Amerika. Perusahaan ini semakin berkembang dan memperdalam bisnis dengan membuat produk-produk yang diminta oleh pelanggan dengan spesifikasi kualitas yang baik demi kepuasan pelanggan. PT Sakae Riken Indonesia mulai produksi pada Oktober 2013, dengan status penanaman modal asing (PMA) dari Jepang. PT Sakae Riken Indonesia saat ini memiliki empat departemen produksi yaitu : injection, plating, painting, dan assembly serta beberapa departemen sebagai pendukung untuk kelancaran produksi antara lain : PPIC, quality control, production preparation, sales, purchasing, HRGA, dan maintenance.

\section{METODE PENELITIAN}

\section{Jenis Penelitian}

Penelitian ini memakai rancangan penelitian kuantitatif. Penelitian kuantitatif adalah "suatu proses memperoleh pengetahuan yang menggunakan data berwujud angka sebagai alat menganalisis keterangan tentang apa yang ingin diketahui”. Observasi ini menerapkan metodekOverall equipment effectiveness. Tujuan dari Observasi ini adalah untuk mengetahui bagaimana produktifitas painting saat ini, apakah sudah baik atau perlur peningkatan, kemudian memberikan alternatif solusi yang bisa diterapkan oleh pengusaha.

\section{Tempat Penelitian}

Penelitian ini akan dibahas mengenai langkah - langkah observasi yang dilakukan. Langkah langkah tersebut seperti lokasi penelitian yang bertempat di PT. Sakae Riken Indonesia kawasan industri Surya Cipta Karawang Jawa Barat bagian produksi painting spray plastik. dengan obyek penelitian semua produk yang diproduksi di bagian painting spray, data-data yang diperlukan serta cara pengambilanidatanya, pengolahan data, improvement, analisis dan rekomendasi yang bisa dilakukan.

\section{Prosedur Penelitian}

Pada observasi ini ada beberapa langkah yang akan dilaksanakan untuk mencapai suatu tujuan dari observasi tersebut. Berikut adalah flow penelitian yang dilakukan : 
ISSN : 2541-6995

E ISSN : 2580-5517

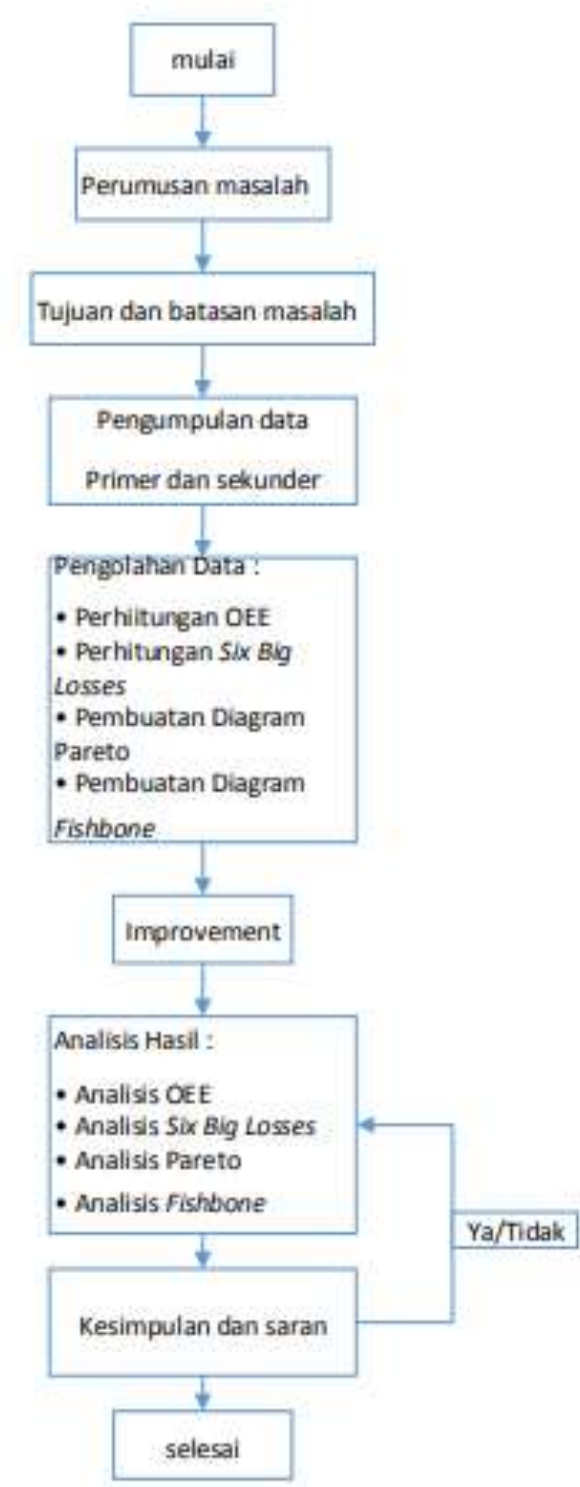

Gambar 1. Flowchat Penelitian

\section{Pengumpulan Data}

Pada tahap ini dilakukan pengumpulan datandengan caralobservasi serta menggunakan data sekunder. Data yang dibutuhkan yaitu: 1. Runing time 2. Downtime 3. Urutan proses produksi 4. Kapasitas produks

\section{Teknik Analisis Data}

Nilai OEE didapat dengan mengendalikan ke 3 rasio utama tersebut. Ketiga rasio adalah sebagai berikut : 
- Avaibility Ratio adalah merupakan suatu ratio yang menjelaskan pemanfaatan waktu yang tersedia sebagai kegiatan pengoperasian mesin atau peralatan menurut Alvira (2015) dalam jurnalnya. Avaibility adalah rasio dari operation time dengan mengurangi down time fasilitas terhadap loading time. Rumus yang dipergunakan yaitu sebagai berikut :

Availability Efficiency = Operating Time $:$ Loading Time x100\% Catatan : Operating Time $=$ loading Time - stop tidak diizinkan Loading Time $=$ Waktu tersedia - stop diizinkan

- Performance Efficiency adalah merupakan rasio yang menjelaskan kemampuan fasilitas dalam mendapatkan suatu barang. Performance didapat dari speed rate dan net operating rate. Menurut Alvira (2015) Operating speed rate peralatan bertolok pada perbedaan antara kecepatan normal dan kecepatan proses aktual. Net Operating Rate mengukur perawatan dari suatu fasilitas selama selang waktu tertentu. Dengan kata lain, Net Operating Rate mengukur apakah suatuiproses tetap normal selama fasilitas bekerja pada speed tertentu. Rumus perhitungan ini adalah sebagai berikut :

Performance Efficiency $=$ Net OperatingTime : Operating Time x 100\% Net Operating Time $=$ Operating Time - Performance Losses Net Operating Time $=$ Cycle Time Produksi : Cycle Actual Time Net Operating Rate =Jumlah Hangger yang Diproduksi x Cycle Time Actual : Net Operation Time Sehingga didapatkan persamaan 14 Performance Efficiency $=$ CycleTime $\mathrm{x}$ Processed Amount : Operating Time $\mathrm{x}$ 100\%

- Quality Ratio Merupakan rasio yang menjelaskan kemampuan fasilitas dalam menghasilkan produk yang sesuai standar (Alvira, 2015). Rumus yang digunakan untuk pengukuran rasio ini adalah sebagai berikut :

QualityRatio = Processed Amount x Amount Deffect : Processed Amount x 100\%

\section{HASIL PENELITIAN DAN PEMBAHASAN \\ Perhitungan Avaibility Ratio}

Tabel 1 Data tabel avaibility ratio bulan Januari s/d Desember 2018 
Afif Hakim, Sri Pramono

Vol 4 No 2

ISSN : 2541-6995

E ISSN : 2580-5517

\begin{tabular}{lllllll}
\hline No & Bulan & Loading time & Down time & $\begin{array}{l}\text { Operation } \\
\text { time }\end{array}$ & Avaibility & Avaibility \% \\
\hline 1 & Januari & 21930 & 60 & 21870 & 0,997 & 99,73 \\
2 & Februari & 19080 & 50 & 19030 & 0,997 & 99,74 \\
3 & Maret & 20100 & 60 & 20040 & 0,997 & 99,70 \\
4 & April & 20100 & 30 & 20070 & 0,999 & 99,85 \\
5 & Mei & 19155 & 28 & 19127 & 0,999 & 99,85 \\
6 & Juni & 10500 & 20 & 10480 & 0,998 & 99,81 \\
7 & Juli & 21000 & 30 & 20970 & 0,999 & 99,86 \\
8 & Agustus & 20010 & 30 & 19980 & 0,999 & 99,85 \\
9 & September & 18150 & 35 & 18115 & 0,998 & 99,81 \\
10 & Oktober & 21940 & 45 & 21895 & 0,998 & 99,79 \\
11 & November & 20070 & 30 & 20040 & 0,999 & 99,85 \\
12 & Desember & 17220 & 40 & 17180 & 0,998 & 99,77 \\
\hline
\end{tabular}

\section{Perhitungan Performance Ratio}

Tabel 2. Data tabel performance ratio bulan Januari s/d Desember 2018

\begin{tabular}{ccccccc}
\hline NO & Bulan & $\begin{array}{c}\text { Jumlah } \\
\text { Produksi }\end{array}$ & $\begin{array}{c}\text { Operation } \\
\text { time }\end{array}$ & $\begin{array}{c}\text { Cycle } \\
\text { Time }\end{array}$ & $\begin{array}{c}\text { Performance } \\
\text { rate }\end{array}$ & $\begin{array}{c}\text { Performance } \\
\text { rate \% }\end{array}$ \\
\hline 1 & Januari & 63499 & 21870 & 0,25 & 0,726 & 72,59 \\
2 & Februari & 63552 & 19030 & 0,25 & 0,835 & 83,49 \\
3 & Maret & 72657 & 20040 & 0,25 & 0,906 & 90,64 \\
4 & April & 69704 & 20070 & 0,25 & 0,868 & 86,83 \\
5 & Mei & 71538 & 19127 & 0,25 & 0,935 & 93,50 \\
6 & Juni & 32670 & 10480 & 0,25 & 0,779 & 77,93 \\
7 & Juli & 64570 & 20970 & 0,25 & 0,770 & 76,98 \\
8 & Agustus & 73850 & 19980 & 0,25 & 0,924 & 92,40 \\
9 & September & 67890 & 18115 & 0,25 & 0,937 & 93,69 \\
10 & Oktober & 83875 & 21895 & 0,25 & 0,958 & 95,77 \\
11 & November & 69450 & 20040 & 0,25 & 0,866 & 86,64 \\
12 & Desember & 66984 & 17180 & 0,25 & 0,975 & 97,47 \\
\hline
\end{tabular}

\section{Perhitungan Quality Ratio}

Tabel 3. Data tabel quality ratio bulan Januari s/d Desember 2018

\begin{tabular}{ccccccc}
\hline NO & Bulan & $\begin{array}{c}\text { Jumlah } \\
\text { Produksi }\end{array}$ & Repair & Straightpass & $\begin{array}{c}\text { Quality } \\
\text { rate }\end{array}$ & Quality \% \\
\hline 1 & Januari & 63499 & 33244 & 30255 & 0,476 & 47,65 \\
2 & Februari & 63552 & 28802 & 34750 & 0,547 & 54,68 \\
3 & Maret & 72657 & 33961 & 38696 & 0,533 & 53,26 \\
4 & April & 69704 & 34924 & 34780 & 0,499 & 49,90 \\
5 & Mei & 71538 & 33893 & 37645 & 0,526 & 52,62 \\
6 & Juni & 32670 & 16874 & 15796 & 0,484 & 48,35 \\
7 & Juli & 64570 & 34896 & 29674 & 0,460 & 45,96 \\
8 & Agustus & 73850 & 37958 & 35892 & 0,486 & 48,60 \\
9 & September & 67890 & 36134 & 31756 & 0,468 & 46,78 \\
10 & Oktober & 83875 & 45085 & 38790 & 0,462 & 46,25 \\
11 & November & 69450 & 36605 & 32845 & 0,473 & 47,29 \\
12 & Desember & 66984 & 37029 & 29955 & 0,447 & 44,72 \\
\hline
\end{tabular}

\section{Perhitungan Overall Equipment Effectiveness}


Afif Hakim, Sri Pramono

Vol 4 No 2

ISSN : 2541-6995

E ISSN : 2580-5517

Tabel 4. Data tabel overall equipment effectiveness bulan Januari s/d Desember 2018

\begin{tabular}{cccccc}
\hline NO & Bulan & $\begin{array}{c}\text { Performance } \\
\text { rate }\end{array}$ & Quality rate & Avaibility & OEE \% \\
\hline 1 & Januari & 0,73 & 0,48 & 1,00 & 34,49 \\
2 & Februari & 0,83 & 0,55 & 1,00 & 45,53 \\
3 & Maret & 0,91 & 0,53 & 1,00 & 48,13 \\
4 & April & 0,87 & 0,50 & 1,00 & 43,26 \\
5 & Mei & 0,94 & 0,53 & 1,00 & 49,13 \\
6 & Juni & 0,78 & 0,48 & 1,00 & 37,61 \\
7 & Juli & 0,77 & 0,46 & 1,00 & 35,33 \\
8 & Agustus & 0,92 & 0,49 & 1,00 & 44,84 \\
9 & September & 0,94 & 0,47 & 1,00 & 43,74 \\
10 & Oktober & 0,96 & 0,46 & 1,00 & 44,20 \\
11 & November & 0,87 & 0,47 & 1,00 & 40,91 \\
12 & Desember & 0,97 & 0,45 & 1,00 & 43,49 \\
\hline
\end{tabular}

\section{Perhitungan Break Down}

Tabel 5. Data tabel break down bulan Januari s/d Desember 2018

\begin{tabular}{ccccc}
\hline No & Bulan & Loading time & Down time & Down time $(\%)$ \\
\hline 1 & Januari & 21930 & 60 & 0,27 \\
2 & Februari & 19080 & 50 & 0,26 \\
3 & Maret & 20100 & 60 & 0,30 \\
4 & April & 20100 & 30 & 0,15 \\
5 & Mei & 19155 & 28 & 0,15 \\
6 & Juni & 10500 & 20 & 0,19 \\
7 & Juli & 21000 & 30 & 0,14 \\
8 & Agustus & 20010 & 30 & 0,15 \\
9 & September & 18150 & 35 & 0,19 \\
10 & Oktober & 21940 & 45 & 0,21 \\
11 & November & 20070 & 30 & 0,15 \\
12 & Desember & 17220 & 40 & 0,23 \\
\hline
\end{tabular}

\section{Perhitungan Set up and Adjustment Losses}

Tabel 6. Data tabel set up and adjustment losses bulan Januari s/d Desember 2018 
Afif Hakim, Sri Pramono

Vol 4 No 2

ISSN : 2541-6995

E ISSN : 2580-5517

\begin{tabular}{ccccc}
\hline No & Bulan & Loading time & Waktu set up (2 shift) & Losses (\%) \\
\hline 1 & Januari & 21930 & 60 & 0,27 \\
2 & Februari & 19080 & 60 & 0,31 \\
3 & Maret & 20100 & 60 & 0,30 \\
4 & April & 20100 & 60 & 0,30 \\
5 & Mei & 19155 & 60 & 0,31 \\
6 & Juni & 10500 & 60 & 0,57 \\
7 & Juli & 21000 & 60 & 0,29 \\
8 & Agustus & 20010 & 60 & 0,30 \\
9 & September & 18150 & 60 & 0,33 \\
10 & Oktober & 21940 & 60 & 0,27 \\
11 & November & 20070 & 60 & 0,30 \\
12 & Desember & 17220 & 60 & 0,35 \\
\hline
\end{tabular}

\section{Perhitungan Idling and Minor Stopages Losses}

Tabel 7. Data tabel idling and minor stopages bulan Januari s/d Desember 2018

\begin{tabular}{cccccc}
\hline No & Bulan & $\begin{array}{c}\text { Jumlah bari } \\
\text { kerja }\end{array}$ & $\begin{array}{c}\text { Loading } \\
\text { time }\end{array}$ & $\begin{array}{c}\text { Non Produktif } \\
\text { Time (menit) }\end{array}$ & $\begin{array}{c}\text { Iddling Minor } \\
\text { Losses (\%) }\end{array}$ \\
\hline 1 & Januari & 23 & 21930 & 2070 & 9,44 \\
2 & Februari & 20 & 19080 & 1800 & 9,43 \\
3 & Maret & 21 & 20100 & 1890 & 9,40 \\
4 & April & 21 & 20100 & 1890 & 9,40 \\
5 & Mei & 20 & 19155 & 1800 & 9,40 \\
6 & Juni & 11 & 10500 & 990 & 9,43 \\
7 & Juli & 22 & 21000 & 1980 & 9,43 \\
8 & Agustus & 21 & 20010 & 1890 & 9,45 \\
9 & September & 19 & 18150 & 1710 & 9,42 \\
10 & Oktober & 23 & 21940 & 2070 & 9,43 \\
11 & November & 21 & 20070 & 1890 & 9,42 \\
12 & Desember & 18 & 17220 & 1620 & 9,41 \\
\hline
\end{tabular}

\section{Perhitungan Reduced Speed Losses}

Tabel 8. Data tabel reduced speed losses bulan Januari s/d Desember 2018

\begin{tabular}{ccccccccc}
\hline & & $\begin{array}{c}\text { Jumlah } \\
\text { hari } \\
\text { No }\end{array}$ & $\begin{array}{c}\text { Loading } \\
\text { Time } \\
\text { (mentan }\end{array}$ & $\begin{array}{c}\text { Cycle } \\
\text { Time } \\
\text { (menit) }\end{array}$ & $\begin{array}{c}\text { Jumlah } \\
\text { Produksi }\end{array}$ & $\begin{array}{c}\text { Ideal } \\
\text { Produktion } \\
\text { Time (Menit) }\end{array}$ & $\begin{array}{c}\text { Operation } \\
\text { time }\end{array}$ & $\begin{array}{c}\text { Losses } \\
\%\end{array}$ \\
\hline 1 & Jan & 23 & 21930 & 0,25 & 63499 & 15874,75 & 21870 & 27,34 \\
2 & Feb & 20 & 19080 & 0,25 & 63552 & 15888 & 19030 & 16,47 \\
3 & Maret & 21 & 20100 & 0,25 & 72657 & 18164,25 & 20040 & 9,33 \\
4 & April & 21 & 20100 & 0,25 & 69704 & 17426 & 20070 & 13,15 \\
5 & Mei & 20 & 19155 & 0,25 & 71538 & 17884,5 & 19127 & 6,49 \\
6 & Juni & 11 & 10500 & 0,25 & 32670 & 8167,5 & 10480 & 22,02 \\
7 & Juli & 22 & 21000 & 0,25 & 64570 & 16142,5 & 20970 & 22,99 \\
8 & Agust & 21 & 20010 & 0,25 & 73850 & 18462,5 & 19980 & 7,58 \\
9 & Sept & 19 & 18150 & 0,25 & 67890 & 16972,5 & 18115 & 6,29 \\
10 & Okt & 23 & 21940 & 0,25 & 83875 & 20968,75 & 21895 & 4,22 \\
11 & Nov & 21 & 20070 & 0,25 & 69450 & 17362,5 & 20040 & 13,34 \\
12 & Des & 18 & 17220 & 0,25 & 66984 & 16746 & 17180 & 2,52 \\
\hline
\end{tabular}


Perhitungan Defect Losses

Tabel 9. Hasil perhitungan defect losses

\begin{tabular}{cccccccc}
\hline No & Bulan & $\begin{array}{c}\text { Jumlah } \\
\text { hari kerja }\end{array}$ & $\begin{array}{c}\text { Loading } \\
\text { Time } \\
\text { (menit) }\end{array}$ & $\begin{array}{c}\text { Cycle } \\
\text { Time } \\
\text { (menit) }\end{array}$ & $\begin{array}{c}\text { Jumlah } \\
\text { Produksi }\end{array}$ & Defect & $\begin{array}{c}\text { Losses } \\
(\%)\end{array}$ \\
\hline 1 & Jan & 23 & 21930 & 0,25 & 63499 & 33244 & 37,90 \\
2 & Feb & 20 & 19080 & 0,25 & 63552 & 28802 & 37,74 \\
3 & Maret & 21 & 20100 & 0,25 & 72657 & 33961 & 42,24 \\
4 & Apr & 21 & 20100 & 0,25 & 69704 & 34924 & 43,44 \\
5 & Mei & 20 & 19155 & 0,25 & 71538 & 33893 & 44,24 \\
6 & Juni & 11 & 10500 & 0,25 & 32670 & 16874 & 40,18 \\
7 & Juli & 22 & 21000 & 0,25 & 64570 & 34896 & 41,54 \\
8 & Agust & 21 & 20010 & 0,25 & 73850 & 37958 & 47,42 \\
9 & Sept & 19 & 18150 & 0,25 & 67890 & 36134 & 49,77 \\
10 & Okt & 23 & 21940 & 0,25 & 83875 & 45085 & 51,37 \\
11 & Nov & 21 & 20070 & 0,25 & 69450 & 36605 & 45,60 \\
12 & Des & 18 & 17220 & 0,25 & 66984 & 37029 & 53,76 \\
\hline
\end{tabular}

\section{Analisis Six big Losses}

Dari perhitungan losses yang telah dilakukan, selanjutnya diurutkan dari yang terbesar ke yang terkecil sehingga diperoleh urutan sebagai berikut :

Tabel 10. Tabel Kumulatif Losses

\begin{tabular}{lccc}
\hline \multicolumn{1}{c}{ jenis losses } & rata rata losses & persentase & kumulatif \\
\hline defect losses & 44,59933289 & 66,37607505 & 66,37607505 \\
reduced speed losses & 12,64597952 & 18,82069599 & 85,19677103 \\
iddling minor and stopage & 9,421626425 & 14,02197168 & 99,21874271 \\
set up and adjust losses & 0,32556188 & 0,484525628 & 99,70326834 \\
Break down & 0,199379582 & 0,29673166 & 100 \\
\hline \multicolumn{1}{c}{ Total } & 67,1918803 & 100 & \\
\hline
\end{tabular}

Setelah diurutkan seperti pada tabel diatas, kemudian dibuatkan diagram pareto. 


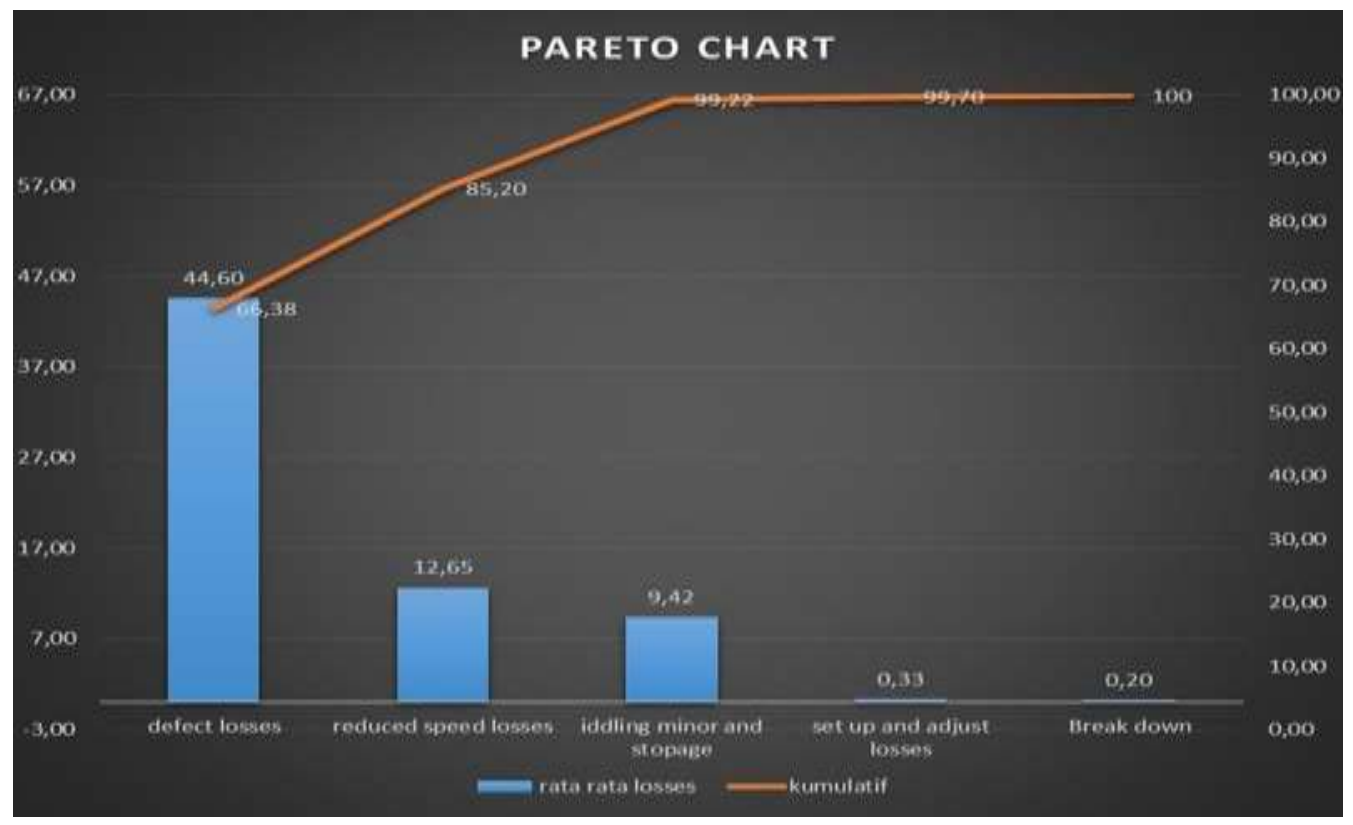

Gambar 2. Diagram pareto

Dilihat dari hasil perhitungan losses didapatkan penyebab Overall Equipment Effectiveness rendah yaitu defect losses. Pada penelitian ini berfokus mencari penyebab losses tersebut. selanjutnya yaitu mencari akar penyebab munculnya losses tersebut. Pencarian akar penyebab dilakukan dengan bantuan tools yaitu diagram fishbone atau diagram sebab - akibat. Berikut analisis losses tersebut yang digambar dalam bentuk diagram sebab - akibat :

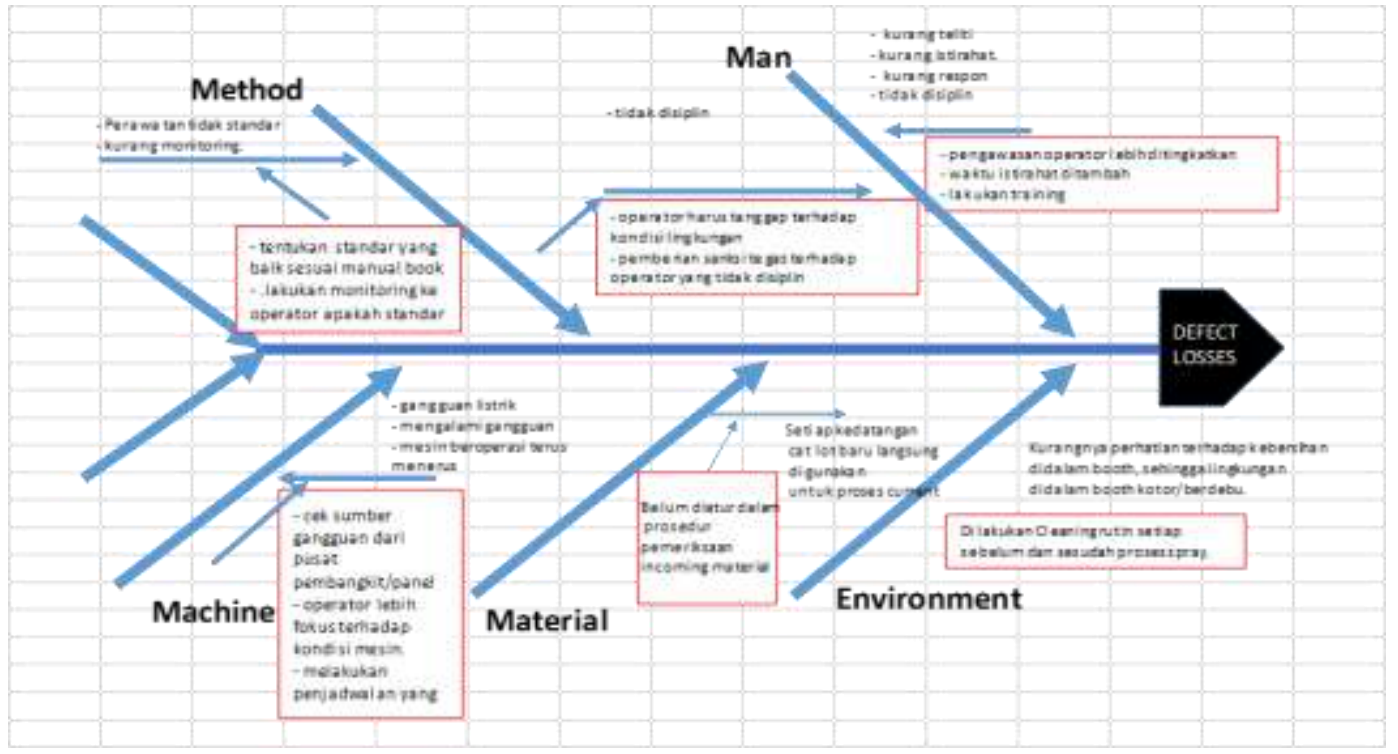

Gambar 3. Fishbone diagram penyebab rendahnya nilai Overall equipment effectivenes Berikut penjelasan dari aspek - aspek losses yang digambarkan dengan diagram 
fishbone :

1. Man (manusia)

Aspek manusia termasuk dalam penyebab dari defect losses. Penyebab dari aspek manusia disini seperti berkurangnya fokus saat bekerja sehingga menghasilkan produk yang tidak sesuai dengan keinginan, serta tidak sesuai dengan standarnya. Salah satu faktornya adalah kelelahan (kurang istirahat), berakibat pada kerja tidak fokus, ketelitian berkurang, bahkan operator bisa saja melanggar aturan yang telah ditetapkan yaitu tentang $5 \mathrm{~S}$.

Dan ada penyabab lainnya yaitu skill yang tidak merata mengakibatkan hasil produksi bervariasi. Dengan perbedaan skill ini banyak hasil produk yang masuk meja repair untuk disesuaikan standar dari perusahaan.

\section{Methode (metode)}

Aspek metode ini juga menjadi salah satu penyebab dalam munculnya defect losses. penyebabnya yaitu perawatan yang tidak standar dan monitoring dari atasan. Sehingga memungkinkan terjadinya produk tidak sesuai dengan standar yang diinginkan. Produk yang tidak standar tadi diharuskan masuk ke meja repair guna penyestandaran kualitas.

\section{Machine (mesin)}

Aspek mesin di sini bukan dalam arti mesin sering rusak yang membuat stop produksi yang dibuktikan dengan nilai persentase avaibility dan performance. Tetapi disini aspek mesin yang menjadi penyebab hasil produksi tidak lolos standar kualitas standar perusahaan. Misalnya jika perawatan tidak teratur pada alat spray mengahasilkan permukaan cat yang tidak merata atau terdapat bintik- bintik kotor dari sisa cat yang tidak dibersihkan pada spray gun atau pompa cat.

4. Material

Pada aspek material disini adalah hal - hal yang menimbulkan defect losses seperti material molding cacat, kesalahan pengambilan part ( serupa tapi beda tipe ). Untuk hal tesebut misalkan masih masuk standar dan dapat direpair harus masuk ke part repair dan perlu tambahan waktu produksi. Dan seharus material cacat tersebut tidak masuk produksi.

\section{Environment (lingkungan)}


Aspek ini dirasa sangat penting dan perlu perhatian dari semua pihak, terutama mengenai kegiatan kaizen 5S. Kenapa 5S menjadi hal yang sangat penting? Sebab musuh utama dari proses spray yaitu debu yang menempel pada part sebelum ataupun setelah proses pengecatan. Dan kegiatan 5S ini dilakukan setiap hari di setiap area proses.

Dari aspek - aspek tersebut bisa disimpulkan bahwa cara yang tepat untuk mengatasi masalah dapat dilakukan dengan pendekatan kaizen 5S atau perbaikan kebiasaan sumber daya manusia melakukan kegiatan 5S (seiri, seiton, seiso, seiketsu, shitsuke).

Tabel 11. Usulan Pemecahan Masalah defect losses

\begin{tabular}{|c|c|c|}
\hline No & Faktor Penyebab & Usulan Penyelesaian Masalah \\
\hline 1 & $\begin{array}{cl}\text { Manusia } \\
\text { - } & \text { Kurang teliti/terampil } \\
- & \text { Kurang istirahat } \\
- & \text { Kurang respon } \\
- & \text { Tidak disiplin }\end{array}$ & $\begin{array}{ll}- & \text { Pengawasan operator lebih } \\
\text { ditingkatkan } \\
\text { - }\end{array}$ \\
\hline 2 & $\begin{array}{cl}\text { Mesin } & \\
\text { - } & \\
\text { - } & \text { Menganguan listrik } \\
\text { - } & \begin{array}{l}\text { Mesin beroperasi terus } \\
\text { menerus }\end{array}\end{array}$ & $\begin{array}{l}\text { Cek sumber gangguan dari pusat } \\
\text { pembangkit/panel } \\
\text { - Generator menggunakan saklar } \\
\text { otomatis } \\
\text { - Sedia suku cadang } \\
\text { - Operator lebih fokus terhadap } \\
\text { kondisi mesin } \\
\text { - Melakukan penjadwalan yang } \\
\text { tepat } \\
\text { Dibuatkan jadwal perawatan }\end{array}$ \\
\hline 3 & $\begin{array}{l}\text { Metode Kerja } \\
-\quad \text { Perawatan tidak standar } \\
\text { - } \quad \text { Kurang Monitoring }\end{array}$ & $\begin{array}{l}\text { - Tentukan standar yang baik sesuai } \\
\text { mamıal book } \\
\text { - Lakukan pelatihan ke operator } \\
\text { - Lakukan monitoring ke operator } \\
\text { apakah standar kerja dilakukan }\end{array}$ \\
\hline 4 & $\begin{array}{l}\text { Material } \\
-\quad \text { setiap kedatangan cat lot } \\
\text { baru langsung digunakan } \\
\text { untuk proses ctarrent }\end{array}$ & $\begin{array}{l}\text { Belum diatur dalam prosedur } \\
\text { pemeriksaan incoming material }\end{array}$ \\
\hline 5 & $\begin{array}{ll}\text { Environment } & \\
-\quad & \text { Kurangnya perhatian } \\
& \text { terhadap } \\
& \text { didalam booth }\end{array}$ & $\begin{array}{l}\text { - Dilakukan cleaning rutin setiap } \\
\text { sebelum dan sesudah proses spray }\end{array}$ \\
\hline
\end{tabular}

\section{KESIMPULAN DAN IMPLIKASI}

Dari hasil pembahasan yang telah dilakukan, maka dapat disimpulkan sebagai berikut :

1. Tingkat OEE untuk produksi painting pada periode Januari s/d Desember 2018 dengan rata - rata sebesar 42,56\% yang merupakan kondisi jauh dari kondisi standard, dimana standardnya adalah 85\%, sehingga produktivitas dikatakan masih rendah. 
ISSN : 2541-6995

E ISSN : 2580-5517

2. Dengan rendahnya produktivitas yang disebabkan oleh tingginya kerugian akibat faktor defect losses sebesar 44,60\% (diagram pareto). Dilakukan perbaikan defect losses tersebut dengan melakukan kegiatan 5S dilingkungan kerja masing - masing.

\section{DAFTAR PUSTAKA}

[1] Almeanazel, O. T. R. (2010). Total productive maintenance review and overall equipment effectiveness measurement. Jordan Journal of Mechanical and Industrial Engineering, 4(4). www.jjmie.hu.edu.jo

[2] Alvira, D., Helianty, Y., \& Prassetiyo, H. (2015). Usulan Peningkatan Overall Equipment Effectiveness (OEE) Pada Mesin Tapping Manual Dengan Meminimkan Six Big Losses. Reka Integra, 3(3). Jurusan Teknik Industri Institut Teknologi Nasional (Itenas) Bandung Email: dianra.alvira@yahoo.com

[3] Kurniawan, Fajar. Graha Ilmu 2013. Teknik Dan Aplikasi Manajemen Perawatan Industri.info@grahailmu.co.id 